\title{
A RECEPÇÃO E PRODUÇÃO DE SENTIDO SOBRE OS ESPAÇOS URBANOS: OLHARES DOS ACADÊMICOS DE CINEMA DA UFPEL
}

\author{
THE RECEPTION AND THE PRODUCTION OF MEANING ABOUT URBAN SPACES: \\ VIEWS OF THE STUDENTS OF CINEMA FROM UFPEL \\ LA RECEPCIÓN Y LA PRODUCCIÓN DE SENTIDO DE LOS ESPACIOS URBANOS: \\ MIRADAS DE LOS ACADÉMICOS DEL CINEMA DE LA UFPEL
}

\author{
Fábio Souza da Cruz \\ Docente da Universidade Católica de Pelotas (ECOS/UCPel). \\ E-mail: fabiosouzadacruz@gmail.com.
}

Guilherme Carvalho da Rosa Docente da Universidade Federal de Pelotas (IAD/UFPel). E-mail: guilherme.rosa@vetorial.net.

\begin{abstract}
Resumo: A pesquisa apresentada tem como objeto as circunstâncias de recepção de um documentário sobre espaços urbanos produzido por acadêmicos de cinema da Universidade Federal de Pelotas/RS (UFPEL). O olhar teórico-metodológico focaliza a recepção desses espaços sob a ótica das interculturalidades (García Canclini, 2006a) e da reconfiguração dos sentidos da vida urbana (Martín-Barbero, 2005). Nesse sentido, são colhidos dados por meio de seis entrevistas realizadas com esses estudantes. O objetivo central é observar como as suas práticas culturais estão articuladas com os espaços urbanos, a partir da vivência de temporalidades agonísticas na América Latina.
\end{abstract}

Palavras-chave: recepção, espaços urbanos, estudos culturais.

\begin{abstract}
The research aims at observing the circumstances of reception of a documentary film about urban spaces produced by film students of the Federal University of Pelotas/RS (UFPEL). The theoretical and methodological view focuses on the reception these spaces on the perspective of interculturalities (García Canclini, 2006a) and the reconfiguration of the meanings of urban life (Martín-Barbero, 2005). Data were collected in six interviews with these students. The central objective is to observe how their cultural practices are articulated in the urban spaces, from their postmodern experience in Latin America.
\end{abstract}

Keywords: reception and production, urban spaces, cultural studies.

Esta obra está licenciada sob uma Licença Creative Commons 
Resumen: La investigación trae como objecto la observación de las circustancias de recepción de un documental sobre espacios urbanos producido por academicos de la Curso de Cinema de la Universidade Federal de Pelotas/RS (UFPEL). La mirada teorico-metodologica se vuelve para la recepción de estos espacios sobre la óptica de las interculturalidades (Garcia Canclini, 2006) y de la reconfiguración de los sentidos de la vida urbana (Martín-Barbero, 2005). En ese sentido, son extraídos datos atraves de seis entrevistas realizadas con eses estudiantes. El objectivo central es observar como sus praticas culturales estan articuladas con los espacios urbanos, a partir de la vivencia de temporalidades agonísticas en la América Latina.

Palabras clave: recepción, espacios urbanos, estúdios culturales.

\section{INTRODUÇÃO}

Este estudo tem como temática uma das vertentes da investigação sobre as relações de comunicação e cultura, que é a observação da cidade como espaço de comunicação e de conflito. Trata-se de uma preocupação recorrente em diversos campos, sobretudo daqueles que compartilham um caminho de orientação antropológica na relação com objetos de pesquisa e que se posicionam metodologicamente onde ocorrem os conflitos e as situações de negociação contemporâneas.

Uma das ocasiões em que essa questão pode ser observada, em termos empíricos, é nos discursos lançados a partir das narrativas audiovisuais: filmes e documentários que trazem como temática, direta ou indiretamente, os conflitos presentes no cotidiano das cidades. Nosso recorte baseia-se nessa premissa, ao trazer a investigação da recepção de um documentário feito por um grupo de estudantes de graduação do curso de cinema e animação da Universidade Federal de Pelotas (UFPEL) no Rio Grande do Sul. O curso é novo e teve seu primeiro ano de funcionamento em 2007. Nesse tempo, os estudantes produziram um documentário, que resultou de um projeto de extensão, justamente tendo como tema os espaços urbanos na cidade de Pelotas. Mais precisamente, o trabalho focaliza as impressões de cada um dos acadêmicos sobre os espaços urbanos. Na produção, denominada "Olhares", surgiu da proposta de que cada estudante deveria indicar um lugar da cidade de sua preferência para falar brevemente sobre o espaço, além de produzir suas primeiras imagens sobre esse local. Com isso em mente, 13 estudantes fizeram suas primeiras produções audiovisuais $\mathrm{e}_{2}$ a partir da proximidade de um dos pesquisadores com os alunos, foi observado o grande interesse que a atividade despertou, não apenas na forma de expressão de cada aluno sobre o local, mas também no compartilhamento de seu olhar com o dos outros estudantes. 
A proposta de investigação começa com a realização de um estudo sobre o momento da recepção do documentário feito com os próprios estudantes que participaram do projeto. Partindo de repertórios teóricos dos estudos culturais de origem britânica e latino-americana para a observação das práticas culturais na comunicação, podemos compreender a dinâmica cultural. Adotamos um modelo de circulação das práticas culturais cunhado por Johnson (2004, p. 35), fruto de uma extensa trajetória teórica sobre a dinâmica comunicacional, fundamentada nos estudos culturais. O modelo considera a perspectiva de produção, circulação e consumo de produtos culturais e estabelece quatro momentos interconectados para essa dinâmica: produção, texto, recepção e culturas vividas. Mesmo pensando nas especificidades para cada um dos momentos, Johnson (2004) ${ }^{1}$ entende o diagrama de circulação da cultura como uma relação de interdependência:

Cada momento depende dos outros e é indispensável para o todo. Cada um deles, entretanto, é distinto e envolve mudanças características de forma. [...] Todos os produtos culturais, por exemplo, exigem serem produzidos, mas as condições de sua produção não podem ser inferidas simplesmente examinando-os como "textos". [...] Para compreender as transformações, pois, nós temos que entender as condições específicas do consumo e da leitura. Essas incluem simetrias de recursos e de poder - materiais e culturais. Também incluem os ensembles existentes de elementos culturais já ativos no interior de milieux sociais particulares ("culturas vividas", no diagrama) e as relações sociais das quais essas combinações dependem (JOHNSON, 2004, p. 33-34).

É interessante ressaltar que, mesmo que esta investigação tenha como olhar principal o momento da recepção, as proposições deste estudo, em parte ressaltadas por Johnson_(2004, p. 33) no circuito da cultura, compreendem uma nova percepção de todo o processo comunicacional que não considera apenas o texto, o conteúdo das mensagens, mas compreende também os objetos de estudo a partir das diferenças culturais e focaliza a atenção nos processos sociais desencadeados pela comunicação, de forma mais ampla. O interesse deste estudo, que implica a opção por caminhos teórico-metodológicos distintos, assemelha-se à proposta dos estudos culturais ao "perceber as intersecções entre as estruturas sociais e as formas e práticas culturais" (ESCOSTEGUY, 2001, p. 43). Muitos outros autores corroboram com esse posicionamento e constituem opções de estudo nesta investigação, que considera, especialmente, a perspectiva latino-americana, através das contribuições de Néstor García-

\footnotetext{
${ }^{1}$ Vale mencionar que o modelo do circuito da cultura é resultado de um longo processo de investigação iniciado por Hall (2003, p. 387), a partir do ensaio Encoding/Decoding, escrito em 1972 e publicado pela primeira vez em 1973. Posteriormente, outros pesquisadores contribuíram para essa reflexão.
} 
Canclini (1999, 2006a, 2006b) e de Jesús Martín-Barbero (1997, 2005). Este último, sobretudo, pela reflexão sobre a perspectiva das mediações culturais aplicadas à dinâmica de circulação cultural.

Essas escolhas condicionam alguns posicionamentos desenvolvidos nesta pesquisa, que tem como objetivo mapear algum conflito observado pelo olhar de cada estudante sobre o espaço urbano da cidade de Pelotas. O registro aqui apresentado ilustra um estágio mais avançado da pesquisa, que teve uma primeira observação feita em 2007 e permitiu, além de indicar a adequação de alguns procedimentos, observar que o mapeamento dos conflitos torna-se um caminho oportuno para perceber em que medida as tensões do urbano estão presentes nas narrativas particulares construídas pelos estudantes. Mesmo que os informantes assumam a condição de receptores e produtores das mensagens estudadas, o interesse recai sobre o momento da recepção qualificado pelas intersecções entre distintos repertórios culturais sobre um mesmo espaço. No entanto, afirma-se, desde já, que esta abordagem sobre o momento da recepção não constitui um fechamento sobre o instante de decodificação das mensagens, como indica a tradição norte-americana, mas considera, segundo o que se diz na América Latina, "a recepção/consumo como um lugar epistemológico e metodológico desde o qual possa representar o processo de comunicação" (MARTíN-BARBERO, 2005, p. 255). Olhar o processo comunicacional a partir deste ponto constitui observar, obrigatoriamente, a relação entre os momentos de comunicação.

\section{QUESTÕES METODOLÓGICAS}

O olhar metodológico central neste trabalho é o desenvolvimento de uma dialética histórico-estrutural que nos permite uma análise historicizada $\mathrm{e}_{2}$ ao mesmo tempo não distante das circunstâncias estruturais do objeto. Essa relação histórico-estrutural teve um papel constituinte nas opções metodológicas dos estudos culturais, desde sua fase de formação e desenvolvimento.

Houve um trânsito entre os dois paradigmas teóricos: o estruturalismo herdado do pensamento marxista e o culturalismo, com uma característica fortemente historicizada. Essas duas posições teóricas estiveram em constante dialética (HALL, 2003, p. 148) e, de certa forma, foram moldando os caminhos teórico-metodológicos utilizados pela tradição britânica dos estudos da cultura, adotada/ postulada, em parte, pelo pensamento comunicacional latinoamericano. Atrelados a esse modelo teórico-metodológico, optamos pela realização de uma 
aproximação com o objeto mediante a combinação de algumas técnicas de pesquisa relacionadas com esse foco específico.

Nosso plano de trabalho é composto pela realização de entrevistas em profundidade ${ }^{2}-$ de caráter participante ${ }^{3}$ - com o grupo de estudantes, a fim de realizar uma análise de maior fôlego teórico ${ }^{4}$. Os informantes foram escolhidos pela participação na produção do documentário, conforme critérios de engajamento e de disponibilidade de participação na investigação. É importante salientar que um dos pesquisadores deste estudo é docente do curso e esta relação permitiu não apenas o acesso aos informantes como também a utilização de alguns repertórios empíricos para a observação dos relatos e da experiência cotidiana. Seguindo alguns passos dos estudos de recepção feitos a partir da perspectiva da interculturalidade, este estudo combina algumas técnicas de pesquisa trazidas da antropologia, como a observação participante, e a etnografia sobre uma perspectiva interpretativa que coloque o objeto de estudo em uma posição dialética, como considera Clifford (1998, p. 34).

Entendida de modo literal, a observação participante é uma fórmula paradoxal e enganosa, mas pode ser considerada seriamente se reformulada em termos hermenêuticos, como uma dialética entre a experiência e a interpretação. [...] Experiência e interpretação têm recebido, no entanto, ênfases diferentes quando apresentadas como estratégias de autoridade. Em anos recentes, tem havido um notável deslocamento de ênfase do primeiro para o segundo termo (CLIFFORD, 1998, p. 34).

Dentro dessa temática, são destacados alguns olhares recorrentes, em boa parte, dos estudos que se dedicam à observação da cidade como (i) inerente tensão dos processos de modernização em conflito com a tradição e como (ii) processos de identificação e a cidade imaginada. Aliados às opções teórico-metodológicas do trabalho, procuramos estabelecer uma relação sócio-antropológica com o objeto, pela utilização de algumas práticas de observação e de interação junto aos informantes e a seu contexto de atividade.

\section{ESPAÇO URBANO COMO PALCO DE CONFLITO}

\footnotetext{
${ }^{2} \mathrm{O}$ material foi colhido de cinco entrevistas face-a-face, e as restantes, via e-mail. Esses dados servirão de base para a realização das análises de pesquisa.

${ }^{3}$ Segundo Thiollent (1985, p. 14), a investigação participante é caracterizada por uma forte participação do pesquisador no processo. O investigador é envolvido de modo "cooperativo ou participativo". A observação participante pode ser compreendida como um método que impele a relação direta com o objeto de estudo e | estimula esta relação_(GUBER, 2001, p. 56).

${ }^{4}$ Vale ressaltar que, em artigo anterior, foram realizadas enquetes com parte do mesmo grupo de entrevistados.
} 
As noções de tempo se alteram. As dinâmicas de trabalho e lazer nas grandes cidades assumem ritmos frenéticos e descentrados. O trânsito reconfigura-se em uma impressão de contínuo caos e de contínua ordem. As praças e parques não têm o mesmo uso de antigamente, não são referenciados pelas pessoas com a mesma "centralidade" que ocupavam há pouco tempo. Há dificuldade em construir metarrelatos em torno de monumentos e obeliscos. Alguns dizem que o centro das cidades está morrendo.

Esses sinais empíricos, de certa forma, demonstram um panorama de crise consensual entre aqueles que se dedicam a observar as percepções do moderno. Desde o poeta Baudelaire (1993) e a figura de seu flâneur parisiense até os dias de hoje, observamos os espaços urbanos como sinais visíveis dessa crise das narrativas do progresso e da utopia tecnológica, isso tudo como uma condição pós-moderna (LYOTARD, 2004). Essa condição ocorre não apenas como a supressão do antigo pelo novo, mas também a partir de uma profunda problematização do presente e de uma perspectiva "pluralista que aceita a fragmentação e as combinações múltiplas entre tradições, modernidade, pós-modernidade, é indispensável para considerar a conjuntura latino-americana” (GARCÍA CANCLINI, 2006b, p. 352).

A trajetória das sociedades ocidentais para a modernidade, sobretudo a dos grandes centros econômicos do hemisfério norte, obedeceu, de certo modo, a um caminho bem delimitado, pois era possível perceber uma fase sucedida por outra fase, a partir das viradas simbólicas e do advento do novo e do progresso. Isso era visível para os agentes sociais que acompanharam a formação dos grandes centros urbanos fundamentados nas interferências da técnica no cotidiano. O automóvel, o rádio, o telefone e outros inventos do século XX foram alguns exemplos dessas viradas simbólicas do novo como algo incontestável e realizador de uma utopia tecnológica. As mudanças espaço-temporais, causadas por estas grandes viradas, foram vivenciadas por um contingente significativo das sociedades. Como demonstra Bauman (2005, p. 28), a trajetória para a formação do estado-nação passou justamente por essa via. Houve tempo para a formação dos grandes discursos como o do estado-nação, o da divisão do trabalho e o do espaço urbano como ápice desse tempo e da materialização de grandes promessas. Esse discurso sobreviveu quase incontestável há mais de um século e forneceu uma identidade nacional indelével, que segundo Bauman (2005, p. 50) "não reconhecia competidores, muito menos opositores". O próprio poeta Baudelaire, no século XIX, é uma prova da vivência radical do moderno, quando seu lirismo descreve o descentramento e o deslumbramento na multidão como um "imenso reservatório de eletricidade": 
O amante da vida universal entra assim na multidão como um imenso reservatório de eletricidade. Pode-se compará-lo, ele mesmo, a um espelho tão imenso quanto esta multidão; a um caleidoscópio dotado de consciência que, em cada um dos seus movimentos, representa a vida múltipla e a graça móvel de todos os seus elementos. É um eu insaciável do não-eu que, a cada instante, o manifesta e o exprime em imagens mais vivas do que a própria vida, sempre instável e fugidia (BAUDELAIRE, 1993 p. 18).

Essa experiência do Pintor da Vida Moderna nada mais é do que uma preconização da experiência urbana que viria a ser problematizada durante todo o século XX. Larrain (2000, p. 16) associa essa imagem do flâneur à vivência vital da modernidade como uma experiência de fragmentação, mobilidade e mudança social que "não apenas rompeu com o modelo do passado, mas também foi caraterizada por um processo permanente de rupturas internas e fragmentação".

Conforme descrevem Sarlo (2000, p. 14) e Martín-Barbero (2005, p. 289), as grandes vias de tráfego, por exemplo, que mudam as paisagens das cidades e reconfiguram a experiência urbana, nada mais são do que a emergência de um espaço de fluxos imediatos que muda a experiência não apenas no sentido de permitir o acesso rápido, mas também no de permitir outra experiência de cidade, por reduzi-la unicamente aos espaços de uso pragmático dos públicos e por não interpelar seus habitantes a outros espaços de diferença e de não-uso. Criam-se, a partir daí, múltiplas cidades e múltiplas noções do espaço desde às daquele que utiliza o sistema de transporte coletivo às daquele que pode ter seu próprio veículo. Tal como a fábula de Italo Calvino, em As cidades Invisíveis, as cidades se multiplicam em outras cidades e "nascem e morrem sem haver se conhecido entre si" (CALVINO in GARCÍA CANCLINI, 1999, p. 82).

Tendo em vista um quadro agonístico de insatisfação com as narrativas do presente, ao situarmos a questão a partir do espaço cultural latino-americano, precisamos compreender a questão dos espaços urbanos como uma problemática. Tal direcionamento se faz necessário porque os processos de urbanização na América Latina seguiram uma trajetória que difere do hemisfério norte. Não foi possível estabelecer uma temporalidade comum, em vista de os processos de urbanização acontecerem de uma forma absolutamente descompassada. O que se pode observar nesse contexto é um grande choque entre a tradição nas sociedades latinoamericanas e a narrativa do moderno, ocorrido em um curto espaço de tempo. Esta análise do 
tensionamento entre tradição e modernidade é complementada pela contribuição do autor chileno, José Joaquín Brunner (1991), que propôs, através de seu trabalho, uma cartografia da modernidade na América Latina. Um dos primeiros pressupostos de Brunner (1991, p. 25) é justamente o tensionamento não como oposição binária, mas como temporalidades que coabitam.

Historicamente constituída, a cidade concretiza as idéias de desenvolvimento que as diferentes sociedades comportam e, com isso, faz com que suas fraturas fiquem mais expostas. A marginalização, os conflitos, a impressão de caos e ordem, o comércio informal e a circulação de produtos culturais nesses contextos são sinais de fratura social que apresentam mais complexificação do que as políticas públicas alcançariam. A cidade é um espaço que, ao mesmo tempo em que assume a concretude dos serviços públicos, do consumo e da cidadania, tem também uma inegável dimensão imaginária e simbólica. Como indica García Canclini (1999, p. 88), "não apenas fazemos a experiência física da cidade, não apenas a reconhecemos e sentimos em nossos corpos o que significa caminhar tanto tempo ou ir parado no ônibus, [...] como imaginamos quando viajamos e construímos visões sobre o que vemos, com quem encontramos". Nesse sentido, por exemplo, a idéia de medo presente no imaginário das cidades é apresentada por Martín-Barbero (2005) e Reguillo (1999) como algo que vai além da existência das ameaças da rua e está ligado à narrativa simbólica da cidade e aos pontos de coesão identitária, muito mais do que à iminência do perigo: "Medos que provêm secretamente da perda do sentido de pertencer, em cidades nas quais a racionalidade formal e comercial foi acabando com a paisagem na qual se apoiava a memória coletiva" (MARTíNBARBERO, 2005, p. 295).

\section{A PERSPECTIVA DAS MEDIAÇÕES}

Responsável pela obra "Dos meios às mediações”, originalmente lançada em 1987, na qual se percebe o desenvolvimento da pioneira perspectiva das mediações, Martín-Barbero é referência indiscutível em estudos de recepção na América Latina. Depois de passar por uma análise crítica de alguns modelos de comunicação clássicos dos paradigmas funcionalistas, o autor estabelece um deslocamento "dos meios para as mediações".

A proposta remete aos lugares de fala de cada pessoa, os quais demarcam uma forma particular de observar, de interpretar e de produzir sentido. Conforme afirma Martín-Barbero 
(1997, p. 291), “[...] na leitura - como no consumo - não existe apenas reprodução, mas também produção, uma produção que questiona a centralidade atribuída ao texto-rei e à mensagem entendida como lugar de verdade que circularia na comunicação".

É importante averiguar, portanto, em que condições as falas estão sendo constituídas e construídas. Essas “posições de enunciação” (HALL, 1996) são individuais, baseiam-se em um contexto particular e, ao mesmo tempo, público, pois também se referem à identidade cultural de cada pessoa, em um processo sempre em construção.

Sob essa perspectiva, Martín-Barbero (1997, p. 292) estabelece três lugares de mediação, a saber: "a cotidianidade familiar, a temporalidade social e a competência cultural". Para o autor, com relação ao primeiro caso, na América latina, as pessoas se reconhecem na televisão; no Brasil, isso não é diferente. No entanto, para que essa situação possa ser entendida, faz-se necessário estudar o cotidiano dessas famílias.

O segundo caso aborda a ligação entre os tempos de produção e as rotinas cotidianas de recepção. $\mathrm{O}$ último aspecto ${ }^{5}$ refere-se às mais variadas bagagens culturais dos componentes da esfera receptiva (particulares, individuais).

Contribuindo para o desenvolvimento desta pesquisa, Orozco Gómez (2000) sinaliza cinco correntes de investigação: efeitos $^{6}$, usos e gratificações, criticismo literário ${ }^{7}$, estudos culturais e análise crítica de audiência. Enquanto as duas primeiras identificam-se com o paradigma positivista, as restantes têm ligações com o hermenêutico.

A corrente dos usos e das gratificações inverte a centralidade no papel do emissor. Agora, interessa saber o que as pessoas fazem com o meio, como se apropriam deste, o que deixa clara a noção de receptor ativo. Este possui necessidades e expectativas, que são individuais e variam de indivíduo para indivíduo.

\footnotetext{
${ }^{5}$ Nesta investigação, trabalharemos com base neste lugar de mediação.

6 No cerne de seus questionamentos, a corrente dos efeitos apresenta a preocupação em saber o que acontece com os receptores expostos a uma determinada mensagem. "Que fazem os meios (ou a mensagem) com a audiência?" Conforme Orozco Gómez (2000, p. 53), "se admite que haja efeitos a curto, médio e longo prazo [...] há efeitos muito importantes e menos importantes [...] e uma vez que se manifestam permanecem, são irreversíveis e, outros, são momentâneos".

7 Por sua vez, o criticismo literário relaciona "os estudos sobre semiótica, temática sintática e as novas correntes alemãs e francesas da estética da recepção" (OROZCO GÓMEZ, 2000, p. 56). Esse modelo tem como objetivo saber o que é produzido a partir do contato entre um leitor e um texto.
} 
Já os estudos culturais indagam qual a função da cultura na interação meio-mensagemaudiência (ORÓZCO GÓMEZ, 2000). A cultura é o centro, o lugar onde perpassam as relações de poder. A comunicação não se entende fora da cultura. Logo, pretende-se saber como a cultura intervém na interação do receptor com determinadas produções e/ou objetos.

Portanto, sendo ativo e dono de uma cultura particular, o receptor produz códigos culturais $^{8}$ : a reprodução, em que aceita tudo o que recebe, o que o constitui em uma espécie de cúmplice do pensar hegemônico; a negociação, quando aceita algumas partes daquilo a que está exposto e outras não; e a resistência, processo que acarreta uma produção alternativa ou contraproposta.

A última corrente - a análise crítica de audiência - implica estudar as produções culturalmente. É feita uma abordagem completa da audiência, que é o elemento principal. Nesse sentido, a recepção consiste em um processo muito complexo no qual interagem diversos elementos que acabam por formar as mediações (lugares de fala) dos receptores.

Na concepção de Orozco Gómez (2000), a perspectiva das mediações implica levar em conta toda uma soma de fatores que podem causar influência no processo de produção de sentido dos receptores, tais como a identidade particular de cada um, a família, a escola, o grupo de amigos, o bairro, o trabalho, a cidade, os meios de comunicação e a disposição dos indivíduos frente a esses, o nível de instrução, sexo, idade, etnia, religião, salário, classe social, ideologia etc. Assim, por intermédio dessa identidade construída - e jamais acabada -, o receptor produzirá significados próprios, particulares e individuais. A total apropriação, a negociação ou até mesmo a resistência plena das mensagens podem ser decorrentes das diferentes mediações anteriormente citadas.

Em sintonia com a proposta metodológica desta pesquisa, segundo Orozco Gómez (2000, p. 83), a investigação qualitativa "é um processo de indagação de um objeto ao qual o investigador alcança através de interpretações sucessivas com a ajuda de instrumentos e técnicas, que lhe permitem envolver-se com o objeto para interpretá-lo da forma mais integral possível". Vale ressaltar que a pesquisa qualitativa tem como maior preocupação a revelação das diferenças contidas no objeto de análise, ao invés de lançar mão de dados estatísticos.

8 Esta categorização do sujeito receptor assemelha-se muito àquela desenvolvida por Hall (2003, p. 387). No entanto, ao invés de "reprodutor", Hall utiliza "dominante"; no lugar de resistência, usa o termo "oposição". O termo "negociação" é trabalhado pelos dois autores. 
Pretendendo detectar posicionamentos, a proposta deste trabalho ganha força na metodologia qualitativa de investigação de Orozco Gómez (2000, 2003). Não há o interesse, aqui, de generalizar os resultados, mas, sim, de verificar (qualitativamente) possibilidades e anseios com base em uma amostra limitada de estudantes.

\section{O OLHAR DOS ACADÊMICOS DE CINEMA E ANIMAÇÃO SOBRE O ESPAÇO URBANO}

Nesta parte, indicamos algumas considerações com relação à recepção do documentário sobre os espaços urbanos de Pelotas, fundadas na entrevista realizada com os alunos do curso de cinema e animação da UFPEL. É digno de nota que esses direcionamentos têm o caráter exclusivo de apontar vetores para o seguimento deste estudo. Não existe a intenção de oferecer uma análise definitiva a partir das reflexões, mas de motivar o prosseguimento da investigação. O repertório empírico que compõe esta parte é composto pelas entrevistas com os seis estudantes participantes e o cruzamento destas com algumas experiências, conforme especificado no início. O questionário, semi-estruturado ${ }^{9}$, apresenta tópicos referentes ao cotidiano de cada estudante no momento de interação com o espaço urbano: onde moram, como se locomovem, quais os bairros que conhecem e como se relacionam com esses espaços.

Os referenciais com o passado para a descrição do espaço urbano são recorrentes na observação dos relatos dos estudantes ${ }^{10}$. Essa consideração não pode ser vista como ocasional, se observarmos empiricamente o contexto da cidade de Pelotas. Com mais de 200 anos de história, a cidade foi uma das primeiras do Estado e possui um grande conjunto arquitetônico de prédios históricos que caracterizam seu espaço urbano. Pelotas remete a uma trajetória precoce no que tange à formação dos espaços urbanos, se comparada às demais cidades gaúchas. Historicamente, especialmente durante o ciclo do charque, que perdurou até o início do século XX, o município foi um dos principais centros econômicos da região sul. Essa dinâmica influenciou boa parte da organização do espaço urbano e do estilo dos prédios de estética erudita, em vista do repertório arquitetônico europeu financiado pelos charqueadores. Mesmo sem uma observação mais aprofundada sobre esse tema, é oportuno observar que a

\footnotetext{
${ }^{9}$ As entrevistas semi-estruturadas trabalham com um roteiro pré-determinado de perguntas, sujeito a alterações de acordo com o andamento da conversa estabelecida com o informante.

${ }^{10}$ Os estudantes permitiram ser identificados (pelos nomes reais) nesta pesquisa
} 
atenção aos aspectos históricos foi recorrente em quase todas as falas dos estudantes. Em boa parte das falas, tal menção não se encontra_essencializada: está sempre posta em conflito com outros posicionamentos ligados à interpelação do moderno, como o que se verifica em:.

Temos avenidas inacabadas ou com trajeto alterado por conveniências alheias ao bem público, as quais poderiam liberar o centro histórico da cidade para que este pudesse ser desenvolvido. Temos atividades comerciais, aqui cito os camelôs, inadequadas para qualquer cidade grande, dia após dia matando os poucos empresários locais que ainda investem na cidade (entrevista com Wagner Oliveira).

A cidade de Pelotas é um local no qual um passado importante impera, ao passo de que as pessoas que nela vivem acabam perdendo-se no sentido de que não sabem o que fazer primeiro, valorizar a história, ou tentar construir o futuro (entrevista com Leonardo Peixoto).

Com a intenção de traçar possibilidades, percebemos que esses aspectos históricos encontram-se sempre em conflito, por conta da relação intricada entre tradicional e moderno, a qual exige que sejam compreendidos sobre o mesmo tempo e não como a supressão de um tempo pelo outro. No relato do estudante Wagner Oliveira, é possível perceber alguns indícios de uma das principais fraturas da modernidade tardia vivenciada pelos países da América Latina, a partir do comércio informal em negociação com o espaço urbano. Como demonstra Larrain (2000, p. 199), o comércio informal é um dos sinais para compreensão da trajetória específica latino-americana no momento em que tem raiz na não-existência de um EstadoNação capaz de regular o sistema econômico que comporte os trabalhadores. Já no segundo relato, do estudante Leonardo Peixoto, o conflito entre o tradicional e o moderno está explícito e relacionado pelo próprio estudante à necessidade de se pensar o futuro a partir do passado. E o espaço urbano é o lugar onde esses desajustes são materializados e percebidos pelos agentes sociais. Aí reside o interesse deste estudo.

Outra perspectiva que se origina na falta de capacidade gestora do Estado na atualidade diz respeito aos contrastes entre pobres e ricos, o que, conseqüentemente, acarreta outros desdobramentos como, por exemplo, a pobreza, a insegurança e a modificação das paisagens urbanas. Conforme relata o estudante Wagner Oliveira,

Moro no bairro Areal. Deveria ser um bairro de classe média alta, no entanto é o bairro que acolhe os maiores contrastes entre pobreza e riqueza na cidade. Tinha tudo para ser o bairro da aristocracia e segurança e é o que possui um dos níveis mais altos de miséria e insegurança. É sujo, muito sujo. Nem 
mesmo os prédios tombados pelo patrimônio se salvam do descaso e da ignorância do povo. Em alguns de seus loteamentos nem mesmo o carteiro entra durante o dia (entrevista com Wagner Oliveira).

Moradora do bairro Centro, Eleonora Loner reforça as palavras do seu colega:

É mais agitado do que o resto [da cidade]. Tem mais barulho, tem alarme de carro o tempo todo na frente da minha casa. [...] no centro não tem jardim, não tem grama, não tem nada... não tem árvore! Se eu tivesse um filho pequeno, eu não iria deixá-lo brincando ali na rua (entrevista com Eleonora Loner).

Já a informante Martha Titze, que costuma transitar bastante pela cidade, também moradora do centro, vê alguns problemas, mas não ressalta as obras públicas e alguns contrastes:

O centro é cheio de carros, as ruas são meio ruins muito estreitas, mas tem uma parte histórica os prédios antigos. É legal passear pelo centro e agora estão asfaltando o centro estão melhorando.Tem umas ruas que eles dão prioridade as ruas estão um pouco melhor, tem lugares que tem mais lixos e menos lixos, o centro é o pior deles o que tem mais lixo e mais gente circulando (entrevista com Martha Titze).

Questionado se ainda nutria o hábito de "viajar" pela cidade, o estudante Wagner Oliveira justifica a mudança de atitudes

Tanto pela insegurança e falta de tempo da vida atual quanto pelos tristes cenários em que se transformaram esses bairros. Ver a ruína de uma comunidade em seus vários matizes não é motivação para viagem alguma. Graças ao meu "DNA" (Data de Nascimento Antiga) conheci todos os bairros da cidade antes que eles se tornassem no que são hoje. Tudo era limpo e até o ar era menos agressivo que hoje. A cidade, hoje, parece moribunda. Entulhada e atulhada de problemas. Não há mais dignidade. O "Cabungueiro" dos anos 60 tinha mais motivos para sentir-se dignificado em sua profissão do que os "recicladores" de hoje em sua vida de miséria e abandono (entrevista com Wagner Oliveira).

Uma das respostas mais surpreendentes ainda, que revela o clima de pessimismo dos estudantes sobre a cidade de Pelotas, é fornecida, de maneira metafórica, por Wagner Oliveira e Fábio Sinoti:

Quando eu estava longe daqui e a saudade me doía no peito, eu lembrava dela como de uma namorada com 17 anos que tive na adolescência. Linda, perfumada e vestida com as cores da primavera. Suas ruas eram como os braços e as pernas dela. Eram longas, lisas... suaves ao toque. E o brilho! Bem, o brilho de suas manhãs e tardes era como os olhos dela e me faziam sonhar [...]. Já de volta. Entrando na cidade eu a vi, a cidade, como uma senhora lá de seus 40 e não sei quantos anos, mas, ainda em forma. Bumbum erguido em uma calça justa como o tráfego que a envolvia e cheia de curvas e insinuações e apelos visuais que me enchiam de ansiedade e de prazer. [...] Caiu a noite, chegou o dia. E entre as brumas de uma manhã cinzenta, pude ver deitada ao meu lado, infelizmente, despida, essa velha e úmida cidade. Agora cheia de 
varizes e rugas. Flácida figura, amorfa, incontida por suas próteses que afloram de sua boca fedida. Cheguei a ficar tonto. Arrependido de estar ali. Só então notei que não era a minha amante e, sim, a cidade que me viu nascer e crescer. Deu-me estudo, trabalho e amigos. Foi o motivo de meu retorno e, para o meu coração, eterno abrigo (entrevista com Wagner Oliveira).

Síndrome de grandeza que impede ela de crescer. É uma cidade pequena que quer manter coisas de cidade pequena. Presa no passado que é a única coisa que faz pensar que ela é grande. E presa em poucas coisas como a Fenadoce e o patrimônio histórico. Só que elas têm outras coisas. Não vai ser uma pavimentação em véspera de eleições que vai transformar numa metrópole (entrevista com Fábio Sinoti).

A participação no documentário foi compreendida por alguns sob a perspectiva de oferecer diferentes formas de leituras dos espaços. Uma das experiências mais agradáveis apontadas por eles foi a de observar a percepção dos outros colegas sobre espaços comuns.

A história contada de cada local esquece, invariavelmente, dos detalhes e das histórias particulares vividas enquanto tal período econômico acontecia ou quando algum prefeito construía uma ponte. Este documentário busca mostrar de forma mais natural o que a cidade de Pelotas é hoje, o que ela instiga nos seus cidadãos (entrevista com Leonardo Peixoto).

Em um documentário no formato do olhares é interessante ver que há diversos modos de ver as coisas, que cada um tem seu modo único de interpretar o lugar retratado (entrevista com Diego Souza).

Mesmo sendo uma visão particular de cada um dos participantes, as imagens ali contidas representam a cidade de Pelotas e são um documento, contendo a visão e opinião de estudantes, sobre partes da cidade onde moram (entrevista com Fábio Sinoti).

Sim tu ia a lugares que tu passa despercebido. Tipo, casas que as pessoas escolheram numa esquina, e tipo tu para pensar a ponte de Rio Grande, eu nunca tinha parado na ponte, e as fotos do semestre seguinte eu fiz na ponte de Rio Grande, passei mais vezes ali depois (entrevista com Martha Titze).

O que se pode perceber a priori é que a prática de registrar o espaço urbano permite que ele seja codificado a partir de uma parcialidade, e que esta, ao invés de restringir seu sentido, fornece várias parcialidades sobre um mesmo espaço que é partilhado pelos estudantes. Cada percepção faz com que haja pequenos olhares sobre uma determinada coisa, ao invés de um grande metarrelato. 


\section{CONSIDERAÇÕES FINAIS}

A partir dos relatos das entrevistas feitas com os estudantes de cinema e animação da UFPEL e do contato com a reflexão teórica sobre a temática dos espaços urbanos e da comunicação, foi possível observar um panorama de tensão que envolve algumas das percepções que os estudantes têm sobre o espaço urbano. Mesmo não tendo ainda fôlego de pesquisa para abarcar esta complexidade, destacamos, como consideração final, a observação de duas particularidades bastante recorrentes na fala dos entrevistados.

A primeira delas está relacionada com a tensão sempre presente entre tradição e modernidade que, na cidade de Pelotas, parece ter preponderância, face às circunstâncias históricas de desenvolvimento da modernidade. Há sempre uma situação de desconexão histórica do passado com o cotidiano e esta conexão dá-se não apenas em nível estrutural, mas também na relação com a experiência sobre a cidade e com as formas de imaginar o espaço urbano. É possível ver como se materializa essa problemática do diálogo entre tradição e modernidade. Pode-se compreender esta questão sobre a noção de García Canclini (2006b, p. 277) que considera um "jogo de usos", uma assimetria que continua existindo entre as duas posições, mas de maneira mais intricada e complexa. Esse jogo de usos não coloca as duas posições como uma simples oposição binária, mas compreende certo dialogismo entre elas. Ambas estão em constante conflito, mas precisam negociar uma com a outra, compartilhar a mesma temporalidade e encontrar uma lógica de desenvolvimento.

A outra questão se refere a uma dimensão imaginária da cidade como um espaço de reconhecimento. A partir da perspectiva das identidades, observamos que a idéia sobre a cidade, muitas vezes, é constituída a partir de uma narrativa bastante particular, mas que, ao mesmo tempo, tem alguns repertórios partilhados pelos informantes. De qualquer forma, observa-se que o vídeo, como narrativa, oferece um espaço de reconhecimento para a cidade; a partir das imagens é possível unificar um discurso sobre a percepção do espaço habitado. Em tudo isso há uma condição imaginária, "grande parte do que nos passa é imaginário porque não surge de uma interação real. Toda interação tem uma cota de imaginário" (GARCÍA CANCLINI, 1999, p. 89). Torna-se oportuno, então, o desenvolvimento destes estudos no sentido de estabelecer uma relação mais aprofundada com as assimetrias formadas pelos contrastes entre a tradição, a modernidade e os imaginários que se formam a partir destas dinâmicas sociais. 


\section{Referências}

BAUDELAIRE, C. 1993. O pintor da vida moderna. Lisboa, Vega, 102 p.

BAUMAN, Z. 2005. Identidade. Rio de Janeiro, Zahar, 110 p.

BENJAMIN, W. 1994. Charles Baudelaire: um lírico no auge do capitalismo. São Paulo, Brasiliense, 272 p.

BRUNNER, J.J. 1991 Cartografias de la modernidad. Santiago do Chile, Dolmen Ediciones, $211 \mathrm{p}$.

CLIFFORD, J. 1998. A experiência etnográfica: antropologia e literatura no século XX. Rio de Janeiro, UFRJ, 319 p.

ESCOSTEGUY, A.C. 2001. Cartografias dos estudos culturais: uma versão latinoamericana. Belo Horizonte, Autêntica, 239 p.

GARCÍA CANCLINI, N. 1999. Imaginarios Urbanos. Buenos Aires, Eudeba, 147 p.

GARCÍA CANCLINI, N. 2006a. Diferentes, desiguais e desconectados: mapas da interculturalidade. Rio de Janeiro, UFRJ, 283 p.

GARCÍA CANCLINI, N. 2006b. Culturas híbridas: estratégias para entrar e sair da modernidade. São Paulo, Edusp, 385 p.

GUBER, R. 2001. La etnografía: método, campo e reflexividad. Buenos Aires, Norma, 146 p.

HALL, S. 1996. Identidade Cultural e Diáspora. Revista do Patrimônio Histórico e Artístico Nacional, 24:68-76.

HALL, S. 2003. Da Diáspora. Identidades e Mediações culturais. Belo Horizonte, UFMG/ Brasília, Representação da UNESCO no Brasil, 434p.

JOHNSON, R. 2004. O que é, afinal, estudos culturais? Belo Horizonte, Autêntica, 236 p.

LARRAIN, J. 2000. Identity and Modernity in Latin America. Cambridge, Polity Press, 250 p.

LYOTARD, J-F. 2004. A condição pós-moderna. Rio de Janeiro, José Olympio, 131 p.

MARTÍN-BARBERO, J. 1997. Dos Meios às Mediações: Comunicação, cultura e hegemonia. Rio de Janeiro, UFRJ, 356 p.

MARTÍN-BARBERO, J. 2005. Ofício de cartógrafo: travessias latino-americanas da comunicação na cultura. São Paulo, Loyola, 478 p.

OROZCO GÓMEZ, G. 1993. Dialéctica de la Mediación Televisiva - Estruturación de estrategias de recepción por los televidentes. Análisi, 15:31-44.

OROZCO GÓMEZ, G. 2000. La Investigación en Comunicación desde la Pespectiva Cualitativa. Buenos Aires, Universidad Nacional de La Plata, 158_p.

OROZCO GÓMEZ, G. 2003. Tel-E-Videncias - Metodologias qualitativas de investigação em comunicação, audiências e meios audiovisuais. Seminário. Porto Alegre, PUCRS. 
REGUILLO, R. 1999. Imaginarios globales, miedos locales la construcción social del miedo En la ciudad. Acessado em 30/07/2008, disponível em:

http://www.eca.usp.br/alaic/Congreso1999/2gt/Rossana\%20Reguillo.doc.

SARLO, B. 2000. Cenas da Vida Pós-Moderna. Rio de Janeiro, Editora UFRJ, 196 p.

THIOLlENT, M. 1985. Metodologia da pesquisa-ação. São Paulo, Cortez, 108 p.

Original recebido em: $24 / 11 / 2011$

Aceito para publicação em: 29/11/2011

Resumo sobre os autores:

1 Fábio Souza da cruz possui graduação em Comunicação Social Jornalismo e Publicidade e Prop pela Universidade Católica de Pelotas (1997), especialização em Teoria do Jornalismo e Comunicação de Massa pela Pontifícia Universidade Católica do Rio Grande do Sul (1998), mestrado em Comunicação e Práticas Sócio Políticas pela Pontifícia Universidade Católica do Rio Grande do Sul (2000), doutorado em Cultura midiática e Tecnologias do Imaginário pela Pontifícia Universidade Católica do Rio Grande do Sul (2006), e pós-doutorado em Direitos Humanos, Mídia e Movimentos Sociais pela Universidade Pablo de Olavide (Sevilha / Espanha 2011). Atualmente é professor titular da Universidade Católica de Pelotas nos cursos de graduação em comunicação social e mestrado em Política Social. Tem experiência na área de Comunicação, com ênfase em Comunicação e Práticas Sócio-Políticas - Pesquisa e ensino e na área de serviço social, com ênfase em políticas sociais, mídia, movimentos sociais, direitos humanos e opinião pública.

http://buscatextual.cnpq.br/buscatextual/visualizacv.do?id=K4770169Z5

2 Guilherme Carvalho da Rosa é mestre em Comunicação pela Pontifícia Universidade Católica do Rio Grande do Sul (2008) com ênfase nos estudos de comunicação e cultura. Possui graduação em Comunicação Social Habilitação Jornalismo pela Universidade Católica de Pelotas (2004). Atualmente é professor assistente da Universidade Federal de Pelotas nas áreas de audiovisual e design digital. Tem experiência de pesquisa na área de comunicação atuando principalmente nos seguintes temas: identidade cultural, relações de comunicação e cultura, pós-modernidade e imagem. Tem experiência técnica nas áreas de webdesign, direção de arte para design, montagem para audiovisual e motion design.

http://buscatextual.cnpq.br/buscatextual/visualizacv.do?id=K4550805H6 